Z. klin. Chem. u. klin. Biochem.

7. Jg., S. 493-497, September 1969

\title{
A New Method for the Determination of Serum Nucleotidase
}

\author{
III. Inbibition of alkaline phosphatase
}

By J.-P. Persijn, W. van der Silk and A. W. M. Bon

From the Department of Clinical Chemistry (Head dr. J.-P. Persijn), Netherlands Cancer Institute, Amsterdam and the
Department of Clinical Chemistry (Head drs. W. van der Slik), State University Hospital, Leiden, Holland

(Eingegangen am 29. April 1969)

The inhibition of the Nucleotidase effect of bone alkaline phosphatase by phenyl disodium orthophosphate is described. The conditions for inhibition and the effect on the normal $5 \mathrm{~N}$ range and the elevated $5 \mathrm{~N}$ values in liver diseases and in cases of high osteoblastic activity are reported.

Die Hemmung des Nucleotidase-Effekts von alkalischer Phosphatase aus Knochen durch Dinatrium-phenylorthophosphat wird beschrieben. Die Bedingungen für die Hemmung sowie der Effekt auf $5^{\prime}$-Nucleotidase im Normbereich als auch auf erhöhten Aktivitäten bei Lebererkrankungen und Fällen hoher Osteoblasten-Aktivität werden dargestellt.

Since REIS (1) reported that human liver homogenate hydrolyses AMP at $\mathrm{pH} 7.5$ more rapidly than other phosphoric esters, serum activity towards AMP at $\mathrm{pH}$ about 7.5 is usually considered to be the result of two enzyme systems, i. e. a 5-nucleotidase system having only affinity for 5-nucleotides and a non-specific phosphatase which is able to split AMP as well. The measured total activity towards AMP is commonly simply referred to as 5 -nucleotidase $\left.(5 \mathrm{~N})^{1}\right)$.

Various attempts have been made to eliminate the interference of non-specific phosphatase in the $5 \mathrm{~N}$ assay, a critical review of these has been given in this journal by Beckmann and coworkers (2) and Persijn and coworkers (3). Summing up the conclusions of this discussion it may be stated that there is a lot of criticism regarding the conditions postulated as inhibiting the concomitant $\mathrm{AP}^{1}$ ) in the $5 \mathrm{~N}$ assay.

Clinically the $5 \mathrm{~N}$ assay is of interest since $5 \mathrm{~N}$ activity increases greatly in liver diseases (4-11). In cases of bone disease $5 \mathrm{~N}$ activity has been reported normal in cases where AP levels are elevated $(8,9)$. It has been pointed out, however, by BE்CKMANN and coworkers (2) that high levels of bone phosphatase can be associated with moderately elevated $5 \mathrm{~N}$ levels.

It is obvious that bone phosphatase has what could be called a "5-nucleotidase effect".

Clinically this does not alter the diagnostic significance of the $5 \mathrm{~N}$ assay as much as would seem at first sight, since in liver diseases, contrary to bone diseases, high levels of AP are commonly associated with high levels of $5 \mathrm{~N}$, presumably as a result of liver metastases.

The differentiation of bone and liver diseases on the basis of moderately elevated $5 \mathrm{~N}$ levels, is difficult, especially if the AP levels are not known.

1) The following abbreviations are used: $\mathrm{ADA}=$ adenosine deaminase (EC 3.5.4.4), $\mathrm{AP}=$ alkaline phosphatase (EC 3.1.3.1), $5 \mathrm{~N}=$ activity towards AMP (EC 3.1.3.5), $\mathrm{PhP}=$ phenylphosphate, $\mathrm{SGPT}=$ serum alanine aminotransferase (EC 2.6.4.2), GP = $\beta$-glycerophosphate.
This is the reason why $5 \mathrm{~N}$ assays are often combined with AP determinations. It is obvious that the $5 \mathrm{~N}$ assay as such would be clinically a more independent parameter if the $5 \mathrm{~N}$ effect of bone phosphatase could be inhibited. The correction for the $5 \mathrm{~N}$ effect of liver phosphatase on the other hand seems to be more interesting from the biochemical than from the diagnostical point of view.

Examples of selective inhibition of the $5 \mathrm{~N}$ effect of bone phosphatase are to be found in studies on cancer. In these cases bone phosphatase appears in the blood and its $5 \mathrm{~N}$ effect is superimposed on the elevated $5 \mathrm{~N}$ activities originating from liver metastases.

Such cases are found

a) if osteoblastic metastases are present, and

b) if recalcification in osteolytic metastases takes place as a response to chemotherapy.

The decrease of the $5 \mathrm{~N}$ level resulting from tumour regression in the liver is masked to some degree by the $5 \mathrm{~N}$ effect of the increasing amount of bone phosphatase. A $5 \mathrm{~N}$ assay in which the residual activity of bone phosphatase on AMP is suppressed would therefore give more exact information about the condition of the liver during the course of therapy etc.

The study of these problem led us to apply a completely new approach to the inhibition of the nucleotidase effect of non-specific phosphatases, especially bone phosphatase.

This was achieved by adding to the incubation medium a second substrate possessing a higher affinity for AP than AMP (e. g. GP or $\mathrm{PhP})^{1}$ ). In this way the AMP was repressed from AP by the competitive second substrate and the net effect was an apparent inhibition of $A P$ in the assay of $5 \mathrm{~N}$ activity. Thus in fact the AP is left in full activity but this is directed towards a substrate of which the hydrolysis products are not measured in the $5 \mathrm{~N}$ assay itself. We have proposed the name of "competitive substrate retention" for this approach. It is obvious that under these conditions the assay of 
$5 \mathrm{~N}$ activity has to be based on measurements not of the inorganic phosphate but of the adenosine released from AMP. In 1968 we introduced such a new method for the assay of $5 \mathrm{~N}$ in serum, which was 3-4 times more sensitive than methods based on the determination of inorganic $\mathrm{P}$. In the new method the $5 \mathrm{~N}$ is measured by a colorimetric reaction with $\mathrm{NH}_{3}$ liberated from adenosine by the enzyme $\mathrm{ADA}^{1}$ ) (3). As can be deduced from data of IpATA (12) and LEYBold and coworkers (13) our method is about eleven times more sensitive than those methods in which adenosine is determined from its rate of deamination by $\mathrm{ADA}$ at $265 \mathrm{~nm}$. Moreover the effect of $\mathrm{PhP}$ on $5 \mathrm{~N}$ activity cannot be studied with such a method since $\mathrm{PhP}$ has a very strong absorbance at $265 \mathrm{~nm}$. A sensitive method for $5 \mathrm{~N}$ is a prerequisite for the investigation of small but important $5 \mathrm{~N}$ effects of bone phosphatase. The new colorimetric method for $5 \mathrm{~N}$ as introduced by us, has been shown to be sufficiently sensitive.

The present paper describes the results of experiments to establish the reaction conditions for the competitive substrate, its concentration and $\mathrm{pH}$ for inhibiting the nucleotidase effect of bone phosphatase and its effect on the normal $5 \mathrm{~N}$ range and on the elevated $5 \mathrm{~N}$ values in cases of liver disease.

\section{Methods and Materials}

\section{Measurement of the $5 \mathrm{~N}$ activity'}

The $5 \mathrm{~N}$ activity was measured using either dialyzed $\mathrm{ADA}$ in ammonium sulphate (3) or $\mathrm{ADA}$ in $50 \%$ glycerol (14).

It should be pointed out that in ref. 14 two corrigenda to ref. 3 are given.

The extinction values of the colour products were read at $625 \mathrm{~nm}$ in a $10 \mathrm{~mm}$ cuvet.

The ADA and AMP (adenosine disodium monophosphate) were purchased from BoeHringer Mannheim, the PhP (phenyl disodium orthophosphate, M. W. = 254) and most of the chemicals used, from British Drug House in England.

The $\mathrm{pH}$ for the study of activity-pH relationship (fig. 5) was measured in the test medium with serum at $37^{\circ}$.

For the $\mathrm{pH}$ range 8.5 to 9.7 , veronal- $\mathrm{Na}_{2} \mathrm{CO}_{3}$ buffers were used. The serum was diluted with four or five times its own quantity of water and the concentration of $\mathrm{ADA}$ doubled because of diminishing $A D A$ activity at the higher $\mathrm{pH}$ values. By separate experiments it was confirmed that $\mathrm{ADA}$ had sufficient activity at the higher $\mathrm{pH}$ values for the rapid conversion of adenosine liberated from AMP.

\section{Measurement of alkaline phosphatase activity}

The AP activities in this paper are quoted in $\mathrm{mU} / \mathrm{ml}$ according to the procedurc of MORGENSTERN and coworkers (15) using the Auto-Analyzer. Incubation takes place in 2-amino-2-methylpropanol buffer ( $\mathrm{pH}$ 10.25) with p-nitrophenyl phosphate as a substrate (normal values $25-116 \mathrm{mU} / \mathrm{m} /$ ).

\section{Results}

Figures 1 and 2 show the $5 \mathrm{~N}$ activities, expressed as the amounts of adenosine released from the same concentration of AMP in the presence of various concentrations of a second substrate ( $\mathrm{PhP}$ ). $\mathrm{PhP}$ did not influence the colorimetric reaction for adenosine as applied in our method for $5 \mathrm{~N}$ determination (tested up to $300 \mu \mathrm{Mol}$

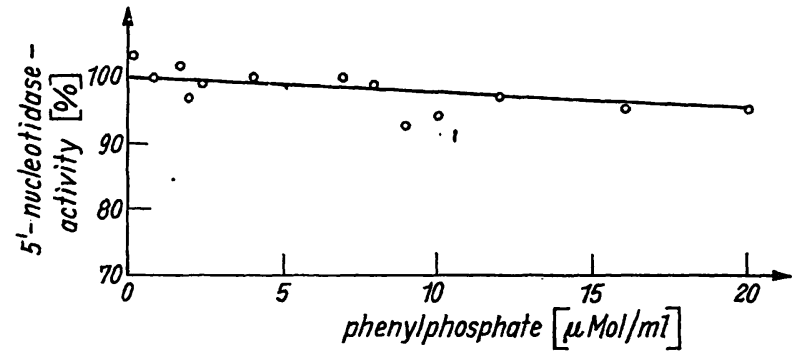

Fig. 1

Effect of various concentrations of PhP ( $\mu \mathrm{Mol}$ per $\mathrm{ml}$ incubation medium) on the $5 \mathrm{~N}$ activity at $\mathrm{pH} \mathbf{7 . 5}$

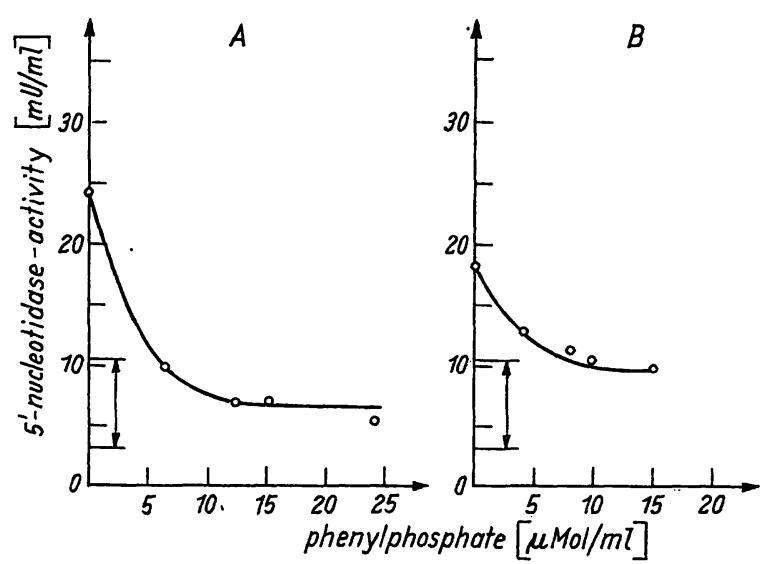

Fig. 2

Effect of various concentrations of $\mathrm{PhP}$ ( $\mu \mathrm{Mol}$ per $\mathrm{ml}$ incubation medium) on the $5 \mathrm{~N}$ activity of sera from patients with high osteoblastic activity

$A=$ patient with hyperparathyroidism $(A P=1440 \mathrm{mU} / \mathrm{ml})$ $\mathrm{B}=$ patient with $M$. Paget (AP $=1000 \mathrm{mU} / \mathrm{m} l)$
The arrows indicate the normal range

per $\mathrm{m} /$ ). The inhibition by the competitive substrate was found to be almost entirely dependent on the type and concentration of this substrate and the $\mathrm{pH}$ of the incubation mixture.

Figure 1 shows the effect of $\mathrm{PhP}$ on the $5 \mathrm{~N}^{\circ}$ activity at $\mathrm{pH} 7.5$ of a pool of serums of patients with liver diseases.

The addition of $\mathrm{PhP}$ to the incubation mixture results in the slowly increasing inhibition of $5 \mathrm{~N}$ activity. At a concentration of $300 \mu \mathrm{Mol}$ the inhibitive effect of $\mathrm{PhP}$ was only approx. $25 \%$.

Results of inhibition experiments in established cases of liver disease using $\mathrm{PhP}$ in concentrations of $8 \mu \mathrm{Mol}$ per $\mathrm{m} l$ incubation fluid appear in Table 1.

The $5 \mathrm{~N}$ level of $576 \mathrm{mU} / \mathrm{ml}$ (patient No. 3) was the highest that had been found in our laboratory for years.

Tab. 1

Inhibition of $5 \mathrm{~N}$ activities by $8 \mu \mathrm{Mol} / \mathrm{ml}$ phenyl phosphate in the incubation medium at pH 7.5 in cases of liver diseases.

\begin{tabular}{lccc}
\hline \multicolumn{1}{c}{$\begin{array}{c}\text { patient No. } \\
\text { diagnosis }\end{array}$} & \multicolumn{2}{c}{ activity } & percentage inhibition \\
& $\mathrm{mU} / \mathrm{ml} l$ & $\begin{array}{c}5 \mathrm{~N} \text { in } \\
\mathrm{mU} / \mathrm{ml}\end{array}$ & by $8 \mu \mathrm{Mol}$ PhP/ml \\
\hline 1. cholangitis & 462 & 84.1 & 1.8 \\
2. liver cirrhosis & 439 & 191 & 1.0 \\
3. liver cirrhosis & 747 & 576 & 2.3 \\
4. biliary cirrhosis & 670 & 110.7 & 5 \\
5. biliary cirrhosis & 447 & 175.5 & 1.4 \\
6. main bile duct & 423 & 71.1 & 3.7 \\
obstruction & 146 & 17.6 & 4.0 \\
7. cirrhosis & 780 & 118.8 & 8.0 \\
\hline hepatitis & & & \\
\hline
\end{tabular}


Tab. 2

Effect of $8 \mu \mathrm{Mol} / \mathrm{ml} \mathrm{PhP}$ in the incubation medium on $5 \mathrm{~N}$ activity of sera with low AP levels. Extinction values at $625 \mathrm{~nm}$ read against appropriate blanks. Conversion factor to $5 \mathrm{~N}$ activity in $\mathrm{mU}: 0.92$

\begin{tabular}{|c|c|c|c|c|c|c|c|c|}
\hline \multirow[b]{3}{*}{ Patient B } & \multirow{3}{*}{$\frac{\begin{array}{c}\text { AP activity } \\
(\mathrm{mU} / \mathrm{m} l)\end{array}}{75}$} & \multicolumn{7}{|c|}{$5 \mathrm{~N}$ assay } \\
\hline & & \multicolumn{3}{|c|}{$\begin{array}{l}\text { no PhP } \\
\text { mean } 5 \mathrm{~N} \text { activity } \\
\qquad(\mathrm{mU} / \mathrm{ml})\end{array}$} & $E_{02}$ & $\mathrm{~nm}$ & \multirow{2}{*}{$\begin{array}{c}\begin{array}{c}8 \mu \mathrm{Mol} / \mathrm{ml} \mathrm{PhP} \\
\text { mean } 5 \mathrm{~N} \text { activity } \\
(\mathrm{mU} / \mathrm{ml})\end{array} \\
30.0\end{array}$} & \multirow{2}{*}{$\frac{\% \text { inhibition }}{2.6}$} \\
\hline & & 0.335 & 0.336 & 30.8 & 0.327 & 0.324 & & \\
\hline Patient $F$ & 129 & 0.374 & 0.383 & 34.9 & 0.375 & 0.368 & 34.2 & 2.0 \\
\hline
\end{tabular}

In Table 2 are data on the effect of $\mathrm{PhP}$ on elevated $5 \mathrm{~N}$ levels of two serums which had normal or only slightly elevated AP levels.

To illustrate the sensivity of our method the extinction values of the duplicate experiments have also been included in the table. It will be seen that $\mathrm{PhP}$ has a very. slight inhibiting effect on $5 \mathrm{~N}$ activity.

Patient B was followed up after operation for breast carcinoma. There were no clinical signs of bone or liver metastases. In May 1968 the levels of 5N, AP and SGPT were normal. In October the $5 \mathrm{~N}$ and SGPT levels were elevated and were still so in Jan. 1969, whereas AP had remained normal.

The bromsulfophthalein test was normal on 20-3-1969. On the basis of the $5 \mathrm{~N}$ levels there is strong suspicion of liver metastases.

The occurrence of elevated $5 \mathrm{~N}$ and normal AP levels in the case of metastatic liver diseases has also been described by SMITH and coworkers (11). It has been observed that a rise of $5 \mathrm{~N}$ can be the precursor of a rise of AP level (16).

Patient $F$ is suffering from M. Hodgkin, which was treated radiologically in June 1968; in the summer of 1968 hypersplenism developed.

On 17-10-1968 extirpation of the spleen took place, after which event $5 \mathrm{~N}$ and AP values increased sharply to 70 and $300 \mathrm{mU} / \mathrm{m} l$ respectively. Leucocyte and thrombocyte counts increased rapidly to normal values. After 12 weeks AP (and SGPT) levels returned to normal, but the $5 \mathrm{~N}$ levels decreased more slowly.

During splenectomy the liver was found normal in appearance and on palpation; the changes in AP and $5 \mathrm{~N}$ values were tentatively interpreted as the expression of the adaptation of the liver to the new demand for RES function after the splenectomy.

The effect of GP on liver phosphatase activity has been published by us in an earlier communication (17). GP represses $5 \mathrm{~N}$ activity to a very slight extent exceeding the s. d. of the test up to about $10 \mu \mathrm{Mol} / \mathrm{ml}$. At higher concentrations however GP-unlike to $\mathrm{PhP}$-reduces the $5 \mathrm{~N}$ activity almost to zero.' The degree of inhibition has been shown to be directly proportional to concentration (17).

In Table 3 the effect of GP on the $5 \mathrm{~N}$ activity of bone and liver phosphatase at $\mathrm{pH} 7.5$ and 8.2 is shown.

Tab. 3

Effect of $\mathrm{GP}$ on the $5 \mathrm{~N}$ activity of bone phosphatase (AP $=1440$ $\mathrm{mU} / \mathrm{ml})$ and liver phosphatase $(\mathrm{AP}=590 \mathrm{mU} / \mathrm{ml})$ at $\mathrm{pH} 7.5$ and 8.2

\begin{tabular}{cccccc}
\hline $\begin{array}{c}\mu \text { Mol/ml GP } \\
\text { in the incubation } \\
\text { medium }\end{array}$ & $\begin{array}{c}\text { Bone phosphatase } \\
\text { pH 7.5 }\end{array}$ & $\mathrm{pH} 8.2$ & $\mathrm{pH} \mathrm{7.5}$ & $\mathrm{pH} \mathrm{8.2}$ \\
\hline & & & & \\
Liver & phosphatase \\
0 & 24.8 & 61.1 & 64.8 & 78.3 \\
GP 2 & 21.6 & - & 62.8 & 74.4 \\
GP 4 & 18.9 & - & 61.5 & 70.5 \\
GP 6 & 18.5 & 36.3 & 61.5 & - \\
\hline
\end{tabular}

The data concern the serum of a patient with hyperparathyroidism and a pool of serums of liver diseases.

A shift of $\mathrm{pH}$ to 8.2 has a strong elevating effect (approx. $140 \%$ ) on the $5 \mathrm{~N}$ activity (without GP) of bone phosphatase, whereas the $5 \mathrm{~N}$ activity of liver phosphatase is only increased by about $20 \%$. The data show that GP is able to suppress the $5 \mathrm{~N}$ activity of bone phosphatase to the normal range only to a limited extent, especially at $\mathrm{pH}$ 8.2. The effect of $\mathrm{PhP}$ on the $5 \mathrm{~N}$ activity at $\mathrm{pH} 7.5$ of bone phosphatase is given in Figure 2. It will be seen from Figure 2 that the presence of $\mathrm{PhP}$ unlike that of GP, reduces the elevated $5 \mathrm{~N}$ effect of bone phosphatase to the normal range.

Table 4 shows that PhP selectively inhibits the $5 \mathrm{~N}$ effect of bone phosphatase in a mixture of serums containing elevated levels of liver and bone phosphatase. In Table 5 the results are given of further inhibition experiments on serums from patients with osteoblastic

Tab. 4

Inhibition of serum bone phosphatase added to serum liver phosphatase

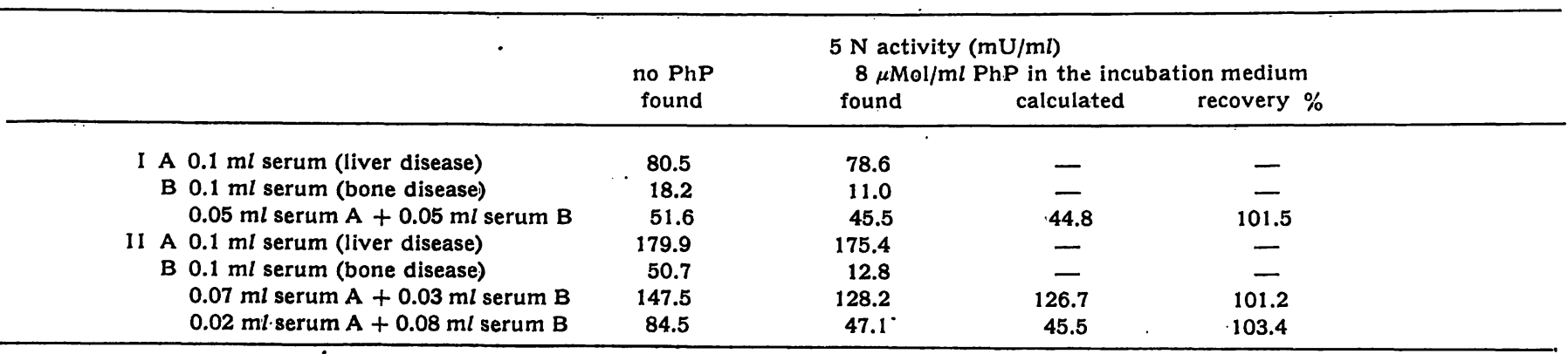


Tab. 5

Effect of $8 \mu \mathrm{Mol} / \mathrm{ml} \mathrm{PhP}$ in the incubation medium on $5 \mathrm{~N}$ level of sera from patients with elevated phosphatase from osteoblastic activities

\begin{tabular}{cccc}
\hline patient & & \multicolumn{2}{c}{$5 \mathrm{~N}(\mathrm{mU} / \mathrm{ml})$} \\
& AP $(\mathrm{mU} / \mathrm{ml})$ & no PhP & with $8 \mu \mathrm{Mol} / \mathrm{ml}$ PhP \\
\hline R & 820 & 16.3 & 10.6 \\
D & 570 & 16.0 & 10.2 \\
C & 3570 & 50.7 & 12.8 \\
B & 715 & 15.7 & 9.2 \\
\hline
\end{tabular}

Tab. 6

Inhibition of $5 \mathrm{~N}$ activities by phenyl phosphate $(8 \mu \mathrm{Mol} / \mathrm{ml})$ in cases of patients with tumours

\begin{tabular}{lccc}
\hline \multirow{2}{*}{ patient diagnosis } & \multirow{2}{*}{ AP $(\mathrm{mU} / \mathrm{ml})$} & \multicolumn{2}{c}{$5 \mathrm{~N}(\mathrm{mU} / \mathrm{ml})$} \\
& & without PhP & with PhP \\
\hline G breast carcinoma & 900 & 172.0 & 165 \\
K breast carcinoma & 1337 & 108.0 & 89.8 \\
$M$ T & 154 & 16.2 & 9.2 \\
Me breast carcinoma & 150 & 28.1 & 26.6 \\
$Z$ cervix carcinoma & 133 & 23.0 & 21.1 \\
W breast carcinoma & 150 & 27.5 & 26.6 \\
\hline
\end{tabular}

AP activities (morbus Paget). Patient $\mathrm{C}$ and $\mathrm{B}$ were both aged 75 .

In Table 6 data are presented from a group of cancer patients. For patient $M$, suspected to have a tumour in the duodenum, the diagnosis was doubtful.

The reason for including this case in the table is that in the serum of patient $M$ an intestinal AP could be demonstrated. The effects of $\mathrm{PhP}$ suggest that it could also be used to inhibit intestinal phosphatase.

In the X-ray films of patient $\mathrm{K}$ the presence of osteoblastic metastases could clearly be demonstrated, whereas patient $G$ was found to have many osteolytic metastases. All patients-except $\mathrm{M}$-were suspected of having liver metastases.

In Table 7 the results of $5 \mathrm{~N}$ assays with and without $\mathrm{PhP}$ are given. These were performed on serums from healthy women who had used contraceptive pills for some years. It has been observed by VAN DER SLIK and Persijn (16) in a preliminary investigation that long

Tab. 7

Effect of PhP on $5 \mathrm{~N}$ activities of sera from women who use contraceptive pills.

\begin{tabular}{ccc}
\hline & \multicolumn{2}{c}{$5 \mathrm{~N}$ activity $(\mathrm{mU} / \mathrm{ml})$} \\
Duration of intake (years) & no PhP & $8 \mu \mathrm{Mol} / \mathrm{ml} \mathrm{PhP}$ \\
\hline 5 & 11.6 & 11.3 \\
3 & 21.1 & 19.2 \\
$3^{1 / 2}$ & 17.1 & 16.7 \\
\hline
\end{tabular}

Tab. 8

$5 \mathrm{~N}$ activities $(\mathrm{mU} / \mathrm{ml})$ of normal subjects $(\mathrm{n}=10)$

\begin{tabular}{ccc}
\hline subject no & no PhP & $8 \mu \mathrm{Mol} / \mathrm{ml} \mathrm{PhP}$ \\
\hline 1 & 9.2 & 8.5 \\
2 & 8.4 & 7.2 \\
3 & 8.4 & 8.2 \\
4 & 9.0 & 8.8 \\
5 & 8.5 & 8.0 \\
6 & 9.5 & 7.7 \\
7 & 8.4 & 8.4 \\
8 & 6.2 & 8.0 \\
9 & 9.1 & 5.4 \\
10 & & 8.6 \\
\hline
\end{tabular}

term use of this pill may result in a significant rise in the $5 \mathrm{~N}$ level.

This matter is now being studied intensively.

To have any diagnostic value the addition of $8 \mu \mathrm{Mol}$ $\mathrm{PhP}$ to $1.0 \mathrm{ml}$ incubation medium of the $5 \mathrm{~N}$ assay should lower the normal range of $5 \mathrm{~N}$ far less than in cases of bone disease. The results of $5 \mathrm{~N}$ assays, with and without $\mathrm{PhP}$, in sera of healthy persons whose ages varied from 29 to 43 appear in Table 8. These results indicate that the serum $5 \mathrm{~N}$ activities of healthy persons are suppressed to a very slight extent.

The suppression by $\mathrm{PhP}$ amounts to an average of $7 \%$. $5 \mathrm{~N}$ assays in the presence of $8 \mu \mathrm{Mol} \mathrm{PhP}$ were made on 60 apparently healthy persons of both sexes, aged 20-60 who declared that they had not recently had any complaint of the liver or the digestive tract, and that they (women) did not use contraceptive pills. The range of individual values was $2.9-10.5 \mathrm{mU} / \mathrm{m} l^{2}$ ) (mean $\pm 2 \times$ s. d.).

The extinction at $625 \mathrm{~nm}$ as a measure of serum activity of $5 \mathrm{~N}$ is proportional to the amount of serum assayed in the presence of $8 \mu \mathrm{Mol} \mathrm{PhP}$ per $\mathrm{m} l$ incubation medium (Fig. 3).

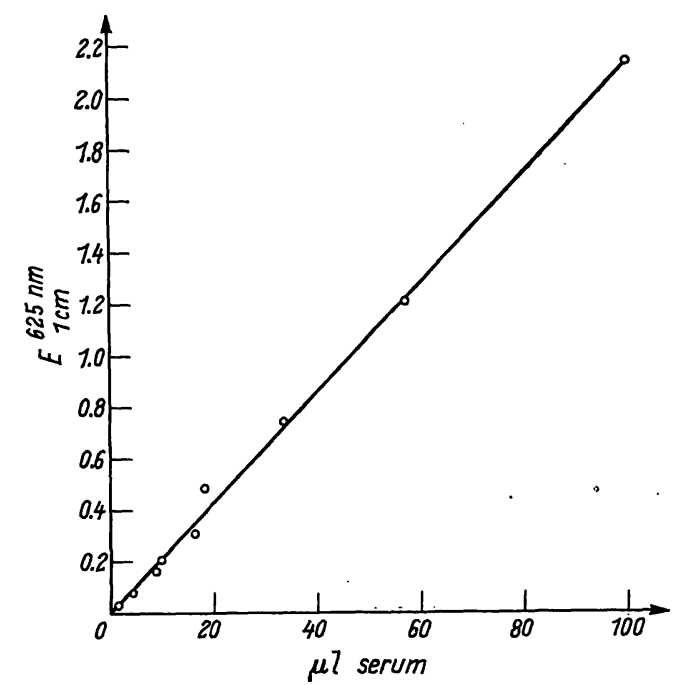

Fig. 3

Relation of optical density to enzyme activity in the presence of PhP $(8 \mu \mathrm{Mol} / \mathrm{ml})$.

\section{Discussion}

It was stated in the introduction that to investigate the $5 \mathrm{~N}$ effect of bone phosphatase and its subsequent elimination for diagnostic purposes, the method applied must satisfy two criteria.

These are:

\section{a) a high sensitivity}

b) non-interference of the inhibitor, e. g. PhP, with the reactions of adenosine on which the $5 \mathrm{~N}$ assay is based.

2) The normal range $(4-14 \mathrm{mU} / \mathrm{ml})$ reported by us in ref. 3 was based on results obtained from phosphate determinations. If with our new method corrections were applied for impurities such as are found in some batches of $A D A$ (see footnote ref. 3) the normal range without $\mathrm{PhP}$ was found to be $5.5-11.5 \mathrm{mU} / \mathrm{ml}$. 
The results show that our method completely fullfils these requirements.

While our work was in progress a report appeared in Nature by BeLfield and Goldberg (18), describing a similar approach to suppressing the $5 \mathrm{~N}$ activity of bone phosphatase. In this approach GP in a concentration of $22 \mu \mathrm{Mol}$ was added to an incubation medium of $\mathrm{pH}$ 7.9. In a communication dealing with the determination of $5 \mathrm{~N}$ in the presence of GP we have made several critical remarks on this approach. Briefly these remarks refer to the insufficient sensivity of the method employed for the $5 \mathrm{~N}$ assay by these authors, and the fact that GP inhibits true $5 \mathrm{~N}$ at concentrations higher than $10 \mu \mathrm{Mol}$ (17). In addition the results presented here (Table 3) suggest that a slight shift in the $\mathrm{pH}$ of the incubation medium will enlarge the discrepancy between $5 \mathrm{~N}$ level in the presence of GP and the normal range. This makes the approach of BELFIELD and GOLDBERG still more indefensible.

It can be assumed that the amount of reduced activity by a competitive substrate represents the $5 \mathrm{~N}$ activity of non-specific phosphatase.

Thus, if we consider Figure $2 \mathrm{~A}$ the depth of the plateau, corresponding to $17.6 \mathrm{mU} / \mathrm{m} l$ is the $5 \mathrm{~N}$ effect of alkaline bone phosphatase. The remaining activity $(7.2 \mathrm{mU} / \mathrm{m} l)$ most likely represents a different phosphatase activity, which is present in the serum of normal subjects, i. e. 5-nucleotidase.

From Figure 1 it can be seen that, at $\mathrm{pH} 7.5$ liver enzymes-unlike those from osteoblasts-have far more affinity for AMP than for $\mathrm{PhP}$, which is convenient if it is desired to repress selectively bone phosphatase activity towards AMP by addition of PhP. Starting from $\mathrm{pH}$ values of about 7.9 and higher, a distinct suppression of non-specific liver phosphatase becomes demonstrable. For $\mathrm{pH} 8.2$ this suppression is illustrated in Figure 4. There are no clinical reasons known at the moment for a $5 \mathrm{~N}$ assay in which non-specific liver phosphatases are to be suppressed. We are therefore in agreement with BECKMANN and coworkers (2), that a $\mathrm{pH}$ value of 7.5 should be taken for the $5 \mathrm{~N}$ assay and that this $\mathrm{pH}$ is also to be prefered if $\mathrm{PhP}$ is used.

For the sake of completeness the $\mathrm{pH}$-activity relationship of liver phosphatase and bone phosphatase is presented in Figure 5. This Figure explains the fact that at lower

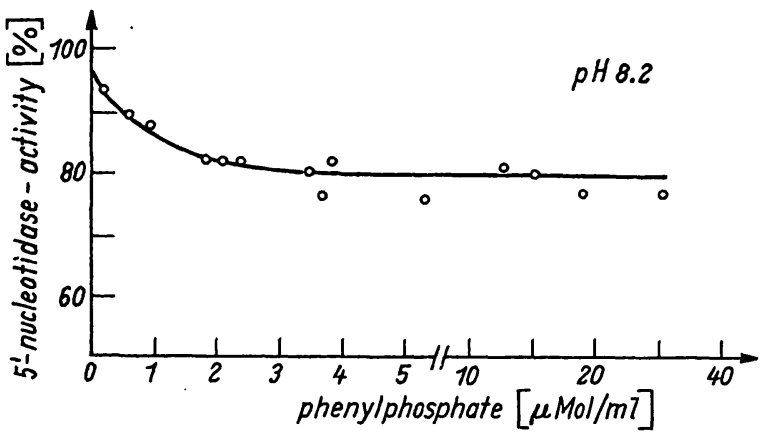

Fig. 4

Effect of $\mathrm{PhP}$ on the $5 \mathrm{~N}$ activity at $\mathrm{pH} 8.2$ in cases of liver diseases

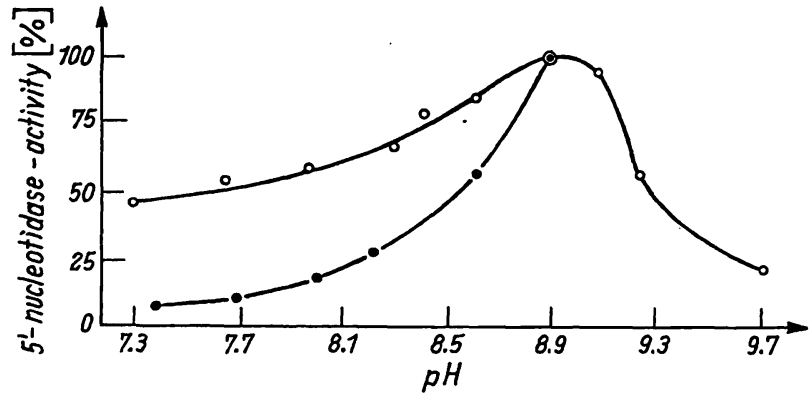

Fig. 5

Effect of $\mathrm{pH}$ on $5 \mathrm{~N}$ activity

$\longrightarrow$ pooled serum from patients with liver diseases. (AP $=587 \mathrm{mU} / \mathrm{ml} ; 5 \mathrm{~N}=95 \mathrm{mU} / \mathrm{ml}$ )

serum with high activity of bone phosphatase

(AP $=1440 \mathrm{mU} / \mathrm{ml} ; 5 \mathrm{~N}=24.8 \mathrm{mU} / \mathrm{ml}$ )

Activity at pH 8.9 was taken as $100 \%$.

$\mathrm{pH}$ (e. g. 7.5) diseases with high osteoblastic activity show only moderately elevated $5 \mathrm{~N}$ levels unlike liver diseases with high AP levels. This discrepancy becomes much less at higher $\mathrm{pH}$ values. Since the results (Fig. 5) show that the direct relationship between optical density and the amount of enzyme is not influenced by $8 \mu \mathrm{Mol} \mathrm{PhP}$ we would propose changing in ref. 3 the preparation of buffered substrate/ADA solution to read: Dissolve $0.250 \mathrm{~g}$ adenosine-5'-monophosphate $\left(\mathrm{C}_{10} \mathrm{H}_{12} \mathrm{O}_{7} \mathrm{~N}_{5} \mathrm{PNa}_{2} 6 \mathrm{H}_{2} \mathrm{O}\right)$ and $0.215 \mathrm{~g}$ phenyl disodium orthophosphate $\left(\mathrm{C}_{6} \mathrm{H}_{5} \mathrm{Na}_{2} \mathrm{PO}_{4} 2 \mathrm{H}_{2} \mathrm{O}\right)$ in $100 \mathrm{ml}$ buffer/ $\mathrm{ADA}$. The solution is prepared fresh before use.

By this modification a standard procedure is obtained for $5 \mathrm{~N}$ assay in which interference by bone phosphatase is reduced.

\section{Acknowledgement}

Thanks are due to Mr. E. Engelsman, m. d., who put the clinical material to our disposal.

\section{References}

1. ReIs, J. L., Biochem. J. 48,548 (1951). - 2. BeCKManN, J., K. LeYbole, and L. WeIsBecker, This Journal 7, 18 (1969). 3. Persijn, J. P., W. van der Slik, K. Kramer, and C. A. De Ruijter, This Journāl 6, 441 (1968). - 4. Kowlessar, O. D., L. J. Haeffiner, E: M. Riley and M. H. Sleisenger, Amer. J. Med. 31, 231 (1961). - 5. Young, I. I., Ann. N. Y. Acad. Sc. 75, 357 (1958). - 6. Bardawirl, C. and C. Chang, Canad. Med. Ass. J. 89,755 (1963). - 7. Dixon, I. F. and M. Purdon, J. Clin. Path. (London) 7, 341 (1954). - 8. SCHWARTZ, M. K. and O. BoDANSKY, Cancer 18, 886 (1965). - 9. CAMpreel, D. M., Bioch. J. 82, 34 P (1962). - 10. FrenKeL, M. and A. J. VAN TrIET, Istael Med. J. 23, 18 (1964). - 11. Smith, K., H. H. VARON, G. J. RACE, D. L.
Paulsen, H. C. Urschel and J. T. Mallains, Cancer 19, 1281 (1966). - 12. Ipata, P. L., Analyt. Biochem. 20, 30 (1967). - 13. LEYBOLD, K., J. BeCKMANN and L. WeIsBeCKeR, This Journal 7, 25 (1969). - 14. Persijn, J. P., W. van der Slik, C. J. Timmer and A. W. M. Bon, This Journal 7, 199 (1969). - 15. MorgenSTERN, S., G. KessLer, J. Auerbach, R. V. FLOR and B. KLEIN, Clin. Chem. New York 11, 876 (1965). - 16. vaN DER SLIK, W. and J. P. Persijn to be published. - 17. Persijn, J. P., W. VAN DER SLIK and C. J. TIMMER, Clin. Biochemistry (Canadian Society of clinical chemists), in 2, 235 (1969). - 18. BELFIELD, A. and D. M. GOLDBERG, Nature (London) 219, 73 (1968).

Dr. J.-P. Persijn, Sarphatistraat 108 Amsterdam C, The Netherlands 